\section{Reinterpreting the Fair and Equitable Treatment Provision in International Investment Agreements as a new and more legitimate Way to Manage Risks}

\section{Azernoosh Bazrafkan and Alexia Herwig.}

\section{Introduction}

International investment agreements (IIAs) emerged in the 1960's as an instrument to lower political risk for foreign investors and to facilitate political risk insurance when investing in developing countries with weak governance structures. ${ }^{1}$ Political risk is constituted by interferences to the investment by host states once the investor has entered the market and which would render the execution of the investment unduly burdensome, deprive the investor of the control or enjoyment of the investment or discriminate or treat the foreign investor arbitrarily. The legal provisions in IIAs include non-discrimination provisions, fair and equitable treatment, full protection and security, rights to compensation in case of expropriations, including indirect regulatory ones with the effect of depriving the investor of the control and benefits of the investment, provisions on free transfer of capital and, occasionally, non-precluded measures clauses as well as stabilization clauses in which the host state promises not to change the regulatory environment affecting the investment.

The unique value of these protections lies in the fact that IIAs allow foreign investors to take the host country government to investor-state arbitration. Arbitration allows the investors to get around lack of impartiality or adequate procedures in litigation before courts of the host state and the awards are

\footnotetext{
" Azernoosh Bazrafkan is a PhD candidate, and Alexia Herwig is Assistant professor, both at the University of Antwerp. An extended version of this report is forthcoming in an OUP volume on Risk in International Law.

${ }^{1}$ Peter Egger and Michael Pfaffenmayr "The Impact of Bilateral Investment Treaties on Foreign Direct Investment", in Karl P Sauvant and Lisa E Sachs (eds), The Effect of Treaties on Foreign Direct Investment: Bilateral Investment Treaties, Double Taxation Treaties and Investment Flows (Oxford: Oxford University Press, 2009), pp. 147 et sqq., at 254. On investment-related political risk, see Thomas W Waelde "Sustainable Development and the 1994 Energy Charter Treaty: between Pseudo-Action and the Managment of Environmental Investment Risk", in Friedl Weiss, Erik Denters and Paul de Waart (eds), International Economic Law with a Human Face (Leiden: Kluwer Law International, 1998), pp. 223 et sqq., 227.
}

automatically enforceable in other states, subject only to very narrow reviewing power of domestic courts.

Starting fromthemid-1990s, foreign investors began using IIAs more and more to challenge risk regulatory policies of host states. Disputes have, for example, concerned landfills, noxious chemicals, tobacco packaging, the termination of green energy subsidies and states' anti-nuclear energy policy. With the coming of age of investment arbitration, criticisms started to be levied against IIAs and investor-state arbitration.

The critique focuses, broadly speaking, on the over-protection of private investor interests when compared to the protection of the public interest of the host state.

The worry of the host state public interest legitimacy critics is that IIAs lead to 'regulatory chill' in developing countries for fear of liability, ${ }^{2}$ that arbitral tribunals have stretched the meaning of IIA provisions to render poorly reasoned and even inconsistent investor-friendly decisions ${ }^{3}$ and that foreign investors obtain special rights in comparison to domestic investors to be free from regulatory interference. ${ }^{4} \mathrm{~A}$ further concern is that strong counter-majoritarian protection of investor rights skews democratic decision- making on the protection of the public interest. ${ }^{5}$ Another worry is that rights to property are overprotected relative to other constitutional or human rights or the public interest. ${ }^{6}$

These critiques raise the thorny question where the balance between protection of political risk of the investor and risk regulation by the host state should be struck. We suggest that viewing IIAs as an instrument to define, manage and distribute risks can bring into sharper relief the answer to this question. In the second section, we will defend

\footnotetext{
${ }^{2}$ Jason Haynes, "The Evolving Nature of the Fair and Equitable Treatment (FET) Standard: Challenging Its Increasing Pervasiveness in Light of Developing Countries' Concerns - The Case for Regulatory Rebalancing", 14 Journal of World Investment and Trade (2013), pp. 114 et sqq., at 120. The liability under IIAs would change the more limited liability of EU member states and the Union, which the CJEU endorsed to prevent regulatory chill. Jan Kleinheisterkamp, "Financial Responsibility in European International Investment Policy", 63 International and Comparative Law Quarterly (2014), pp. 449 et sqq., at 457 and "Who is Afraid of Investor-State Arbitration? Unpacking the Riddle of "No Greater Rights" in the TTIP", 5 IISD Investment Treaty News (2014), 9, 10.

${ }^{3}$ Susan D Franck, "The Legitimacy Crisis in Investment Treaty Arbitration: Privatizing Public International Law Through Inconsistent Decisions", 73 Fordham Law Review (2005), pp. 1521 et sqq., passim; Haynes, supra, note 2, at 121.

${ }^{4}$ Jan Kleinheisterkamp, "Investment Treaty Law and the Fear for Sovereignty: Transnational Challenges and Solutions", 78 Modern Law Review (2015), pp. 793 et sqq., at 797-9.

${ }^{5}$ Gus Van Harten, "Investment Treaty Arbitration, Procedural Fairness, and the Rule of Law", in Stephan W Schill (ed), International Investment Law and Comparative Public Law (Oxford University Press, 2010), pp. 627 et sqq., at 656-7.

${ }^{6}$ Kleinheisterkamp, supra note 4, at 803 [with further references].
} 
the view that IIAs are instruments of risk management. The third section will highlight how thinking about risk sharpens our understanding what is at stake concerning the legitimacy of risk management through IIAs because it brings into focus the issue of when risks are fairly distributed and how the fair and equitable treatment provision should consequently be interpreted.

\section{How do IIAs Construct, Manage and Allocate Risks?}

IIAs provide guarantees for foreign investors in transition economies while they undertake national legislative reforms. ${ }^{7}$ The most frequently invoked guarantees during investorstate arbitration that minimize the exposure of foreign investors to political risks in the host country are compensation for (indirect) expropriation and fair and equitable treatment standard. ${ }^{8}$

IIAs require host states to internalize the cost of discriminatory or otherwise unfair and inequitable treatment of investors and their expropriation of investments by creating a liability risk for the host state for the payment of damages. From the investor's perspective, a large negative pecuniary externality (political risk) gets reduced through the prospect of damages for acts illegal under IIAs. From the host economy's perspective, its legal liability risk may entice investors to invest, thereby yielding a net collective benefit.

\section{Indirect Expropriation}

In order to be legal, IIAs require that an expropriation must be undertaken for a public purpose in a non-discriminatory manner, with due process of law and accompanied by the payment of prompt and adequate compensation. This provision seems to be based on an anti-utilitarian recognition that noone should be deprived of their possession for the greater benefit of society. Clearly, no-one would ever reasonably assent to such a risk. IIAs here regulate risk imposition as a form of wrong, that is, of harming without justification.

However, measures tantamount to expropriation are subject to the same obligation. Arbitral tribunals have recognised that a host state's regulatory measures can

\footnotetext{
Egger and Pfaffemayr, supra note 1, at 254

Ruth Ginsburg, "Political Risk Insurance and Bilateral Investment Treaties: Making the Connection", 14 Journal of World Investment and Trade (2013), pp. 743 et sqq., at 947.
}

deprive investors to such a significant extent of the enjoyment, control and use of their property as to amount to expropriation. The difficult question that has kept arbitral tribunals busy is whether the duty to compensate the investor can somehow be avoided if the host state has valid reasons for the measure. Three approaches exist. Some tribunals find a regulatory measure expropriatory soley based on its effects, that is, if it results in a substantial deprivation of the foreign investor's benefit of its investment regardless of the host state's intent. ${ }^{9}$ Some tribunals determine whether the nondiscriminatory, bona fide and legitimate public purpose measure was proportionate - despite the adverse impact on the foreign investment. ${ }^{10}$ Other tribunals have attempted to find a balance between the host state's right to regulate in the public interest and the protection of the investor's rights; held that a non-discriminatory regulation for a public purpose, which is enacted in accordance with due process and which affects a foreign investment, is not deemed expropriatory and compensable unless specific commitments were given by the government to the foreign investor to refrain from such regulation. ${ }^{11}$ The latter two approaches, which focus on the reasonableness of the regulation and its proportionality, permit host states greater scope to regulate risks. They also suggest that a set-back to an interest is not a wrong if there are good, public reasons for the regulation and the host state showed concern towards the investor by affecting her minimally and only with appropriate due process. ${ }^{12}$ This seems consistent with the earlier framing of the risk as amoral wrong from which the investor should be protected.

The purely effects-based approach is not consistent with this framing because it disregards the reasons for the regulatory intervention. In fact, it potentially suggests quite the opposite, namely that the investor should be able to impose harm on the population of the host state without justification, i.e. wrong them, inasmuch as the

\footnotetext{
9 Occidental v Ecuador (UNCITRAL/LCIA Case No. UN3467, Final Award, 1 July 2004), paras. 85, 92; Siemens v Argentina (ICSID Case No ARB/02/8, Award, 17 January 2007), para. 270; Santa Elena v Costa Rica (ICSID Case No. ARB/96/1, Final Award, 17 February 2000), para. 72; AES v Hungary (ICSID Case No ARB/07/22, Award, 23 September 2010), paras. 14.3.1-14.3.4; Metalclad v Mexico (ICSID Case No ARB(AF)/97/1, Award, 30 August 2000), paras. 103 and 107.

${ }^{10}$ Azurix v Argentina (ICSID Case No ARB/01/12, Award, 14 July 2006), paras. 309-12; Tecmed $v$ Mexico (ICSID Case No ARB(AF)/00/2, Award, 28 May 2003), paras. 121-2.

${ }^{11}$ Methanex $v$ United States (UNCITRAL/NAFTA, Final Award, 3 August 2005) Part IV-Chapter D, paras. 7-9.

${ }^{12}$ We use the notion of a public reason here in its Kantian sense as a reason everyone affected can reasonably assent to because each one would will it as a general rule.
} 
amount of compensation due for a potential regulatory expropriation makes it no longer viable to regulate in the public interest. It is small wonder that arbitral awards have attracted criticism for being poorly reasoned, surely as a matter of doctrinal interpretation but apparently also as a matter of principle.

\section{Fair and Equitable Treatment}

The fair and equitable treatment obligation establishes an absolute minimum standard of treatment of investors. A prevalent formulation is that the host state should treat the investments from the other signatory state in accordance with international law, including fair and equitable treatment and full protection and security provision. ${ }^{13}$ Lacking in more specific content, the cumulative result of several arbitral awards is that it now includes: (i) stability, predictability, consistency with the host state's legal framework; (ii) protection of legitimate expectations; (iii) denial of justice and administrative due process; (iv) transparency; and (v) reasonableness and proportionality in relation to host states' governmental action. ${ }^{14}$

The purpose of FET is viewed as protecting the foreign investor against unfair practices by the host state, such as arbitrary cancellation of licenses, harassment of an investor through unjustified fines and penalties, or creation of other barriers to disrupt a business. ${ }^{15}$ However, arbitral tribunals have found a breach of the fair and equitable treatment standard in situations in which the host state did not necessarily act in bad faith but, rather, in an improper and discreditable or unreasonable way. For example, the tribunal in Occidental $v$ Ecuador seems to limit host state's sovereign power to make changes in tax rates. ${ }^{16}$ Likewise, in a series of disputes against Argentina during its financial crisis, the changes in gas tariff rates to provide public utility service were found in breach of the fair and equitable treatment standard. ${ }^{17}$ In Metalclad v Mexico, uncertainty

\footnotetext{
${ }^{13}$ See, e.g. North Atlantic Free Trade Agreement, Article 1105 ${ }^{14}$ Kenneth J Vandevelde, "A Unified Theory of Fair and Equitable Treatment", 43 NYU Journal of International Law and Policy (2010), pp. 43 et sqq., at 104-6.

${ }^{15}$ UNCTAD 'Fair and Equitable Treatment', UNCTAD Series on Issues in International Investment Agreements II (United Nations, New York and Geneva, 2012) 7.

${ }^{16}$ Occidental $v$ Ecuador, supra note 9, paras. 183-6 and 190-1.

${ }^{17}$ Suez et al v Argentina (ICSID Case No ARB/03/19, Decision on Liability, 30 July 2010), para. 226; LG\&E v Argentina (ICSID

Case No ARB/02/1, Decision on Liability, 3 October 2006), paras. 129 and 158; Enron $v$ Argentina (ICSID Case No ARB/01/3, Award, 22 May 2007), para. 263.
}

on the face of the domestic law over which authority was competent to require permits for landfills for hazardous waste, coupled with affirmations by state officials that municipal permits were not required, led to the breach of the FET provision. ${ }^{18}$ According to Hirsch, investment awards have found breaches of FET in essence on only two grounds; either because specific governmental representations, assurances or contractual obligations preexisting the changed circumstances; or because a legislative change was accompanied by procedural defects. ${ }^{19}$ The first ground suggests that FET operates like the concept of detrimental reliance on a promise in contract law which serves to create new relations of liability between parties. The wrong to the investor would here lie in the promise not being kept while the investor is set-back in her interests.

Yet, several other awards have taken all circumstances, including the political and socioeconomic conditions of the host state but also host state's legitimate regulatory interests, into consideration when assessing the reasonableness of investor's legitimate expectation. ${ }^{20}$ This broader approach in which all relevant reasons are considered for assessing whether a frustration of expectations results in a breach of FET again sees the purpose of FET's protection against risk quite differently; namely as preventing the wronging of an investor when there are no good reasons for a set-back in her interests.

The inconsistent perspectives on what political risk is ultimately at stake with the FET undermine the legitimacy of investment arbitration and IIAs. What is more, it is possible that the exact same conduct of a host state meeting all criteria of procedural propriety and therefore being consistent with FET in the first instance could violate the FET in the second instance in which the state additionally gave specific assurances about its regulatory framework. This also prompts the interesting question whether the absence of specific assurances (the first step towards legitimate expectations) in the first case possibly discriminates against the investor in violation of the Most-Favoured-Nation obligation, which requires the most advantageous treatment given to one foreign

\footnotetext{
${ }^{18}$ Metalclad $v$ Mexico, supra note 9, paras. 74 and 79-86.

${ }^{19}$ Moshe Hirsch, "Between Fair and Equitable Treatment and Stabilization Clause: Stable Legal Environment and Regulatory Change in International Investment Law”, 12 Journal of World Investment and Trade (2011), pp. 784 et sqq. at 790, 792-799.

${ }^{20}$ Parkerings $v$ Lithuania (ICSID Case No ARB/05/8, Award, 11 September 2007), paras. 331-2; Duke Enegry v Ecuador (ICSID Case No ARB/04/19, Award, 18 August 2008), para. 320; Saluka v Czech Republic (UNCITRAL, Partial Award, 17 March 2006), paras. 304-8.
} 
investor to be extended to all other foreign investors protected by an IIA. It might thus be the case that the true baseline of FET is that of protecting legitimate expectations as promises having to be kept absolutely.

\section{A new Approach to Construction, Management and Allocation of Risk through a Reinterpretation of Fair and Equitable Treatment}

FET is seen as an absolute standard. However, the terms fairness and equity are actually relational concepts. If someone is treated fairly and equitably, her treatment is in balance with the rights, interests and claims of others, too. In this sense, the FET provision holds the key for unlocking the legitimacy of how IIAs are to construct, manage and allocate risk. When we study legitimacy, we are interested in these questions of fair balance. Moreover, it is unimaginable that other treaty norms with the same scope of application as an unqualified norm rationae materiae and which evokes fairness and equity could be interpreted as contrary to fairness and equity. Or, to simplify, that a legal norm, which establishes a prescriptive "ought", would require conduct which is unfair and inequitable and still be a legal norm.

Since IIAs are so centrally about construing, managing and allocating risk, it is only natural that their concept of fairness should be based on fairness of risk distribution. When we are interested in questions of fairness and equity, we are ultimately interested in agency, that is, in the question whether a person was treated as an end in herself and not as a means to an end. Where a person is an agent, i.e. acts freely, she must also be responsible for the consequences. Risk and responsibility are ultimately connected to agency in the following, abstract way: The imposition of an important risk onto us through the acts of another reduces our agency because we are now no longer completely free to go about our plans in quite the same way we would have before the imposition of risk occurred. We have instead to reckon with the possibility that the risk could materialize and adjust our plans as needed. However, risk (and its counterpart, possible benefits) also allows us to expand the scope of our agency into the future. We can, for instance, pay a sum of money today for a possibly increased return in the future (i.e. invest).

The connection between risk, responsibility and agency is also well- illustrated in the account of ambition-sensitive egalitarian distributive justice of Ronald Dworkin that works with notions of risk. He distinguishes between brute luck and option luck. ${ }^{21}$ Brute luck is a situation of bad luck completely outside of the control and anticipation of any individual, while option luck is a risk which is statistically knowable and therefore insurable. ${ }^{22}$ Dworkin's category of option luck points to an ideal category of luck: where a person's essential needs and desires are satisfied equally to those of others, any risky decisions of hers are freely taken. ${ }^{23}$ Consequently, if she chooses to assume risks, she ought rightly to suffer the consequences.

The political risk at issue in IIAs is of a mixed nature. It is not outside of the realm of the known that developing countries present higher political risk. After all, this is why IIAs were first created and why they are predominantly signed between a developed, capital-exporting and a developing, capitalimporting country. However, the precise political risk cannot be calculated with absolute certainty and the investor has little control over its occurrence. In fact, we suggest that there is a distinct class of political risks at issue in IIAs which are systemic risks because they become triggered when the host state starts to develop as a result of influx of foreign capital, services, and its own exports, leading to more or different demand for risk regulation. Regulatory needs are likely to change from basic concerns over prevention of infectious diseases, preventing malnutrition and crime to more complex risks of food safety, environmental protection and others. In relation to systemic risks, Aaron James has argued that responsibility for 'systemic' risks is collective and that amorally acceptable distribution of systemic risks must therefore be equal. ${ }^{24}$ Equality will be achieved if expected ex ante benefits exceed expected ex ante losses for everyone regardless of starting positions and no less risky alternative is available at a reasonable cost to anyone else. ${ }^{25}$

We suggest that tribunals should follow this inquiry in determining whether an investor has received fair and equitable treatment. They should investigate whether an anticipation of development of a particular

\footnotetext{
${ }^{21}$ Ronald Dworkin, "What Is Equality ? Part 2:Equality of Resources", 10 Philosophy and Public Affairs (1981), pp. 283 et $s q q$. , at 292-304.

${ }^{24}$ Aaron James, "The Distinctive Significance of Systemic Risks", forthcoming in Ratio Juris, manuscript on file with the authors, at 13-14, 25.

${ }^{25} \mathrm{Ibid}$, at 13-14. An illustrative example put forth in the literature and discussed also by James would be the practice of authorizing ambulances to speed on the way to hospital notwithstanding the risk of accident to bystanders this creates.
} 
host state is a necessary reason for the investor to realise a higher expected profit than in another location and whether the ex ante expected political risk remained lower than the expected profit and the developing country lacked the capacity to lower the risk at the time the investment was made. When these conditions are met, we suggest that a fair and equitable treatment claim based on changed regulatory circumstances and frustrations of expectations by an investor must fail. Furthermore, tribunals must also ensure themselves that the population of the host state is treated fairly and equitably in the sense that the investor's unregulated conduct does not pose a threat to their essential security interests and human rights protections. Anything less would not constitute a fair and equitable treatment because it would demand the host state's population to bear concentrated losses that simply cannot be countervailed by an expectation of general social development.

\section{Conclusion}

Understanding the fair and equitable treatment provision in IIAs as being about fair distribution of risk in the sense that foreign direct investment is a mutually beneficial arrangement for each person involved, allows for a more unified conception of the risk at stake in IIAs in terms of political risk of the investor and the host state's right to regulate. The conception is ultimately that of a set-back in interest is not backed up by comprehensive public reason. The immediate implication for investment tribunals is that FET requires a context-specific, comprehensive assessment of the reasons for the investment location to determine whether the investor's expectations were legitimate; and of the countervailing reasons in favour of a regulatory change. The tribunal in Parkerings $v$ Lithunania hence understood the essence of the legal test correctly and should be followed. 